OPEN ACCESS

International Journal of Applied Research in Social Sciences

P-ISSN: 2706-9176, E-ISSN: 2706-9184

Volume 2, Issue 4, P.No. 97-110, October, 2020

Fair East Publishers

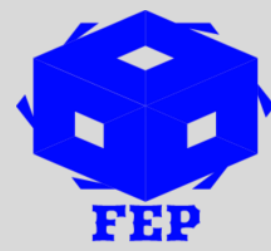

Journal Homepage: www.fepbl.com/index.php/ijarss

\title{
ICT RESOURCES AVAILABLE FOR TEACHERS IN BASIC SCHOOLS IN ADANSI ATOBIASE IN THE ADANSI SOUTH DISTRICT OF GHANA
}

\author{
Justice Agyei Ampofo ${ }^{1,2}$ Antwi Abrefi Abigail ${ }^{3}$ \\ ${ }^{1}$ University for Development Studies, Tamale (Ghana) \\ ${ }^{2}$ University of Education, Winneba (Ghana) \\ ${ }^{3}$ University of Professional Studies, Accra (Ghana)
}

*Corresponding Author: Justice Agyei Ampofo

Corresponding Author Email: papajusty@gmail.com

Article Received: 13-09-20

Accepted: 05-10-20

Published: 15-10-20

Licensing Details: Author retains the right of this article. The article is distributed under the terms of the Creative Commons Attribution-Non Commercial 4.0 License (http://www.creativecommons.org/licences/by-nc/4.0/) which permits non-commercial use, reproduction and distribution of the work without further permission provided the original work is attributed as specified on the Journal open access page.

\begin{abstract}
Information and Communication Technology (ICT) has become one of the basic building blocks of modern society hence ICT resources are key in effective teaching and learning. However, there seems to be paucity of studies on ICT resources available in public basic schools in general and Adansi Atobiase in particular. This research seeks to bridge this knowledge gap by finding out ICT resources available for teachers in their teaching at public basic schools in Adansi Atobiase in the Adansi South District of the Ashanti Region of Ghana. Study methods include, the use of questionnaire (close and open-ended questions). A total of 40 respondents (40 teachers) who took part in this study were purposively selected. The results indicate that the basic school teachers in Adansi Atobiase do not have all the ICT available resources to facilitate teaching and learning. The study also found out that ICT resources such as ICT teacher, laptop, computers, projectors, ICT laboratory and internet access are not available at basic schools in Adansi Atobiase. It emerged from the study that availability of ICT resources, students' readiness to embrace technology, teachers' readiness to embrace technology, availability of technical support, stable power supply and intention to facilitate teaching and learning are the factors that influence the teachers' usage of ICT resources in teaching and learning in basic schools in Adansi Atobiase. The study recommends that ICT basic resources like computers, laptops and infrastructures should be provided to the basic schools in Adansi Atobiase in the Adansi South District of the Ashanti
\end{abstract}


Region of Ghana for effective use of ICT in teaching and learning at the basic schools since it is the basic stage of equipping the youth with the necessary skills and knowledge for national development. The study finally recommends that basic school teachers in the Adansi South District especially those in Adansi Atobiase should be given the necessary training in ICT usage so that they become familiar with modern pedagogy of imparting knowledge and skills, and possible become part of curriculum structure for their professional training. Lastly the study recommends that modern ICT laboratories should be built in Adansi Atobiase to accommodate enough students at time looking at their population size for effective and efficient teaching and learning environment.

Keywords: ICT, Resources, Teachers, Basic Schools, Adansi Atobiase, Adansi South District, Ghana.

\section{INTRODUCTION}

Information and Communication Technology (ICT) has become, within a very short time, one of the basic building blocks of modern society (Afful-Dadzie, 2010; Ampofo, 2019). Many countries now regard the mastering of the basic skills and concepts of ICT as part of the core of education, alongside reading, writing and numeracy (Boakye, 2008). The role of ICT in teaching and learning is rapidly becoming one of the most important and widely discussed issues in contemporary education policy. To this extent, developed countries in Europe and America have made legislative provisions on the imperative use of ICT in the instructional process (Bracey, 2005).

Although developing countries, including Ghana, have become aware of the invaluable role of ICT in effective teaching and learning, they have not been able to make significant progress in improving education through this medium (Boakye, 2008). In Africa, concerted efforts have been made by many governments including Ghana to initiate internet connectivity and ICT training programmes (Agyei, 2011). Such programmes are expected to link schools and libraries around the world to improve education, enhance cultural understanding, develop vital skills of creativity and also to encourage problem-solving and independent thinking which the youth need for survival in the global setting.

From the early 1990s, education stakeholders in Ghana have been concerned about how teachers and students use computers in schools and how their use supports learning. In 2004, the Parliament of Ghana passed into law Ghana's ICT for Accelerated Development (ICT4AD) policy, which is currently at various stages of implementation. This policy represents the vision of Ghana in the information age and addresses 14 priority focus areas including accelerating human resource development and promoting ICT in education.

Efforts are gradually being made to provide educational institutions with computers and to encourage ICT as an integral component of the educational process so as to meet the demands and challenges of globalization. It is for the above reasons that the role of the teacher is very important in rolling out this innovation (Adebi-Caesar, 2012). This is because teachers are at the centre of curriculum change and they control the teaching and learning process. Therefore, they must be able to prepare the young generation for the current technology in which the competency to use ICT to acquire and process information is paramount (Martin, 2003). Education in the $21^{\text {st }}$ century requires teachers to be at the cutting 
edge of knowledge. For the achievement of full ICT incorporating into all subjects, there is the need to find out ICT resources available for teachers in their teaching.

\section{REVIEW OF RELATED LITERATURE}

\section{Information and Communication Technology}

According to Chen (2008), ICT comprises the use of at least a computer and the internet as well as computer hardware and software, networks, and a host of devices that convert information (text, images, sounds, and motion) into general digital formats. Information and Communication Technology (ICT), in this context, represent a new approach for enhancing the dissemination of information and will be used, applied, and incorporating it into learning on the basis of conceptual understanding and from the earliest times when computers were commercially available, they could be found in use in educational institutions, and educators (Fan, 2012) argued that computers should be used to support learning.

\section{Teachers' ICT Usage}

The incorporating of Information and Communication Technologies can help revitalize teachers and students. This can help to improve and develop the quality of education by providing curricular support in perceived difficult subject areas (Fan, 2012). To achieve these objectives, teachers need to be involved in collaborative projects and development of intervention change strategies which would include, teaching partnerships with ICT as a tool (Goyal, 2020). Teachers' attitudes are major predictors of the use of new technologies in instructional settings (Idoko, 2010).

Teachers' attitude toward ICT shapes not only their own ICT experiences, but also the experiences of the students they teach. According to Inan (2010), three conditions are necessary for teachers to introduce ICT into their classrooms; teachers should believe in the effectiveness of technology, teachers should believe that the use of technology will not cause any disturbances, and finally teachers should believe that they have control over technology. Afful-Dadzie. (2010) reached similar conclusions in their research study: "Training efforts are generally welcomed by teachers but consistent support and extensive training is necessary in order for them to consider themselves able to integrate ICT in their teaching methodologies."

According to Amengor (2011), one of the major factors affecting people's attitude toward a new technology is related to the features of the technology itself. Rogers' points out five basic features of technology that affect its acceptance and subsequent adoption: relative advantage, compatibility, complexity, observability, and trialibility. Thus, a new technology will be increasingly diffused if potential adopters perceive that the innovation: (a) has an advantage over previous innovations; (b) is compatible with existing practices; (c) is not complex to understand and use; (d) shows observable results and (e) can be experimented with on a limited basis before adoption.

Preparing students for real life in our technological and diverse world requires that teachers embed ICT in significant learning experiences (Braun \& Kraft, 1995). However, research studies show that most teachers do not make use of the potential of ICT to contribute to the quality of learning environments, although they value this potential quite significantly (Ampofo, 2019).

Cowie (2008) conducted case studies in three primary and three secondary schools, which focused on innovative pedagogical practices involving ICT. Amenyedzi (2011) concludes 
that the benefits of ICT will be gained, "when confident teachers are willing to explore new opportunities for changing their classroom practices by using ICT." As a consequence, the use of ICT will not only enhance learning environments but will also prepare the next generation for their future lives and careers (Chen, 2008).

\section{METHODOLOGY}

\section{Research Methods}

A mixed method approach was adopted for this study, involving both qualitative and quantitative data collection methods. Quantitative data were collected using questionnaires. These tools captured the required data on ICT resources available for the teachers and the factors that influence the teachers' usage of ICT resources in teaching and learning. Qualitative data was captured using Key Informants Interview (KII) guides with key stakeholders at the school levels. Specific key stakeholders were asked questions that are relevant to this study.

Mixed method approaches were used for this study because it can answer a broader and more complete range of research questions because the researcher is not confined to a single method or approach (Ampofo, 2020). Mixed-methods can also provide stronger evidence for a study's conclusions through convergence and corroboration of findings (Ampofo, 2019). The researcher used a concurrent mixed methods design in the current study. In a concurrent approach, two or more data collection instruments are administered within the same time frame. The researcher collected both forms of data (questionnaire and interview) at the same time during the study, and then integrated these data into the interpretation of the overall results (Ampofo, 2020).

The purpose of using a mixed method design was to use both the responses obtained from the questionnaire and those from the interviews to provide a comprehensive analysis of the research questions asked. A secondary reason was the possibility of using the results from one instrument to confirm or corroborate findings from the other (Ampofo, 2017).

\section{Research Design}

The research is a descriptive survey through which views and opinions were sampled from teachers. Ampofo (2020) views descriptive survey as a design that portrays accurately the characteristic of particular individual situations or groups. In other words, the descriptive survey is a research method that is non-experimental and deals with the relating among nonmanipulated variable. A descriptive survey also provides a quantitative or numeric description of trends, attitudes, or opinions of a population by studying a sample of that population. It includes cross-sectional and longitudinal studies using questionnaire or structured interviews for data collection, with the intent of generalizing from a sample to a population (Ampofo, 2017).

The descriptive survey was considered the most appropriate design for conducting this research because information gathered from the descriptive research can be meaningful or useful in diagnosing a situation since it involves describing, recording, analyzing and interpreting conditions that exist. The descriptive survey was again considered the most appropriate design for conducting this study because it is the one that deals with things as they currently are (Creswell, 2013; Ampofo, 2020). Descriptive survey design also helped achieved the goal of the study, which was to find out the ICT resources available for public basic school teachers in Adansi Atobiase in the Adansi South District of the Ashanti Region 
of Ghana. The study identified the ICT resources available to the teachers and the factors influencing the usage of these resources in teaching and learning.

\section{The Study Area}

The study was conducted in all the two public Junior High Schools in Adansi Atobiase in the Adansi South District of Ghana. The researcher's work experience as a teacher has helped me gain access to the information needed for the successful completion of this study. The schools are within my locality hence, reducing the cost as well as risk involved in travelling. This make the data collection process easy and convenient.

\section{Population}

The target population consisted of the teachers of the two public Junior High Schools in Adansi Atobiase. The two public Junior High Schools have a teacher population of about 40 teachers. The teachers are the targeted group because they are teaching and incorporating ICT into teaching and learning is of more relevant to them. This is what Table 1represents.

Table 1

Sample Size

\begin{tabular}{ll}
\hline & Teachers \\
\hline Population & 40 \\
Sampled & 40 \\
\hline Source: Field Survey (2017)
\end{tabular}

\section{Sample Size and Sampling Techniques}

All the teacher of the two public Junior High Schools in Adansi Atobiase (namely Atobiase Roman Catholic Junior High School and Atobiase D/A Junior High School) were purposively selected for this study. Here all teachers were considered because they are those that are teaching and know the available ICT resources. A census survey was conducted. A census survey was conducted among the 40 teachers. According to Ampofo (2020), "a census is feasible when the population is small and variable, any sample we may draw may not be representative of the population from which it is drawn." Considered the target population in question (Teachers in the two public Junior High Schools in Adansi Atobiase), it is most appropriate to use the census survey.

\section{Instrumentation}

Questionnaire was used to collect data from respondents in this study. The questionnaire was both close ended and open ended questions with options like (Very common, Common, Uncommon, Very uncommon, Strongly Agree, Agree, Disagree, Strongly Disagree and Ranking). It was divided into three sections which are as follows: Section A - Personal data and Section B on the ICT resources available for the teachers and Section C on the factors that influence the teachers' usage of ICT resources in teaching and learning. Questionnaires required less time and money compared to other methods like focus group discussions (Ampofo, 2020).

\section{Pretesting of the Instrument}

A pilot study was conducted in Almighty Junior High School which has the same sociodemographic as that of two public Junior High Schools in Adansi Atobiase selected for this study. The questionnaires were administered to five (5) teachers. The pilot study was done to improve the reliability of instrument. Changes were made to questions deemed inappropriate after the pilot study.

\section{Validity of the Instruments'}

A research instrument is said to be valid when it measures what it is supposed to measure. 
Face validity is in relation to the misunderstanding and misinterpretation of the question. This was checked by way employing pretesting method. Content validity on the other hand, refers to the capacity of the instrument to prove adequate coverage of a topic. Adequate preparation of the instrument under guidance of expert opinion and pre-testing of the question helped established the content validity.

\section{Reliability of the Study}

Reliability has to do with an instrument consistently producing the same result every time it is used. The test retest method was used to test for the reliability of the instrument. The questionnaires were administered to teachers of Adansi Atobiase Almighty Junior High School which has the same socio- demographic as that of the four selected public Junior High Schools for this study. The same questionnaires were administered to them after two weeks. A correlation coefficient of 0.8 alpha levels was obtained which is considered reliable.

\section{Data Collection Procedure}

The researchers obtained an informed consent from the head teachers of the two public Junior High Schools to seek their approval and access to the school, students and other documents that would facilitate the study. The head teacher of each school conveyed a meeting with teachers to inform them about the purpose of the research and their cooperation. The participants were told of the purpose, time, venue and how to answer the questionnaires. They were also assured of their confidentiality and anonymity. The researchers selfadministered the questionnaires to all the forty (40) teachers selected for the study to clarify issues that are not understandable to them.

\section{Data Analysis Technique}

Analysis of data provided facts and figures that enabled interpretation of the results and reaching conclusions from the findings of the study. All items of the questionnaires were coded. Items in the form of Likert scale were rated between 4-1, with 4 being the highest and 1 being the lowest. Questionnaires were edited to ensure that clear, legible, relevant, and appropriate responses had been provided. The coded items and their corresponding frequencies were fed into the computer using the SPSS software programme. Data were analyzed using simple percentages and frequencies.

\section{RESULTS AND DISCUSSION OF RESULTS}

\section{Demographic Characteristics of Respondents (Teachers)}

One item of the questionnaire gathered data on the respondents (teachers) gender which is presented in Table 2 below.

Table 2

Sex Distribution of Respondents
\begin{tabular}{lll} 
Sex & $(\mathbf{F})$ & $\mathbf{( \% )}$ \\
\hline Male & 25 & 62.5 \\
Female & 15 & 37.5 \\
\hline Total & $\mathbf{4 0}$ & $\mathbf{1 0 0}$ \\
\hline
\end{tabular}
Source: Field Survey $(2017)$

The sex distribution of teachers' respondents from Table 2 show that majority of respondents were males as males represented as $25(62.5 \%)$ and $15(37.5 \%)$ were females. The implication is that, male respondents outnumbered female respondents. This finding is in disagreement with Amengor (2011) who reveal that, most female teachers are in teaching in urban areas of Ghana. The findings of this study is also in disagreement with a study by 
Amenyedzi (2011), it could be partly due to female teachers joining their husbands who work in urban areas hence avoid working in rural areas.

Another aspect of the questionnaire gathered data on the age distribution of respondents and this is what Table 3 presents.

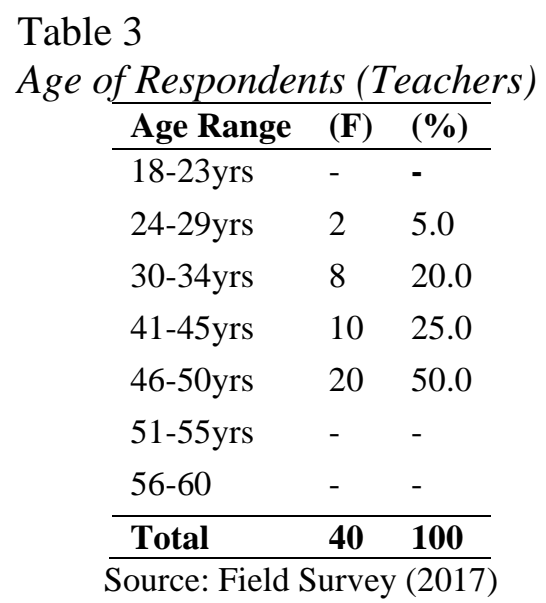

The results form table 3 shows that majority of respondents were between the age group 4650 representing $20(50.0 \%)$, followed by those between the age group of 41-45 representing $10(25.0 \%)$, followed by those between the age group 30-34 representing 8 (20.0\%), followed by those between the age group 24-29 representing 2 (5.0\%). The implication is that, majority of the teachers teaching in public basic schools in Adansi Atobiase in the Adansi South District of the Ashanti Region of Ghana were older form 30 years.

Another aspect of the questionnaire gathered data on the teaching experience of respondents and this is what Table 4 presents.

Table 4

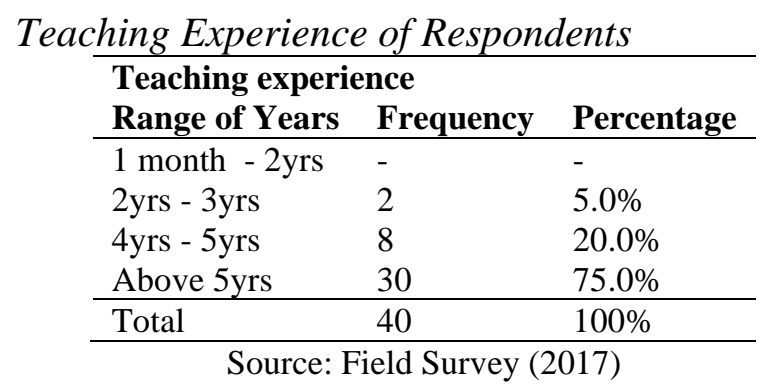

From table 4, the most opted number of years of teaching experience was above 5 years. Seventy-five percent of the teachers had teaching experiences above five years, $20 \%$ for $4-5$ years and $5 \%$ for the 2-3 years of teaching. It can be assumed that, all the teachers have adequate work experience and can provide reliable information for the study.

Table 5

\begin{tabular}{|c|c|c|}
\hline Response & Frequency & Percent \\
\hline Diploma & 35 & $87.5 \%$ \\
\hline First Degree & 5 & $12.5 \%$ \\
\hline Masters & - & - \\
\hline Total & 40 & 100.0 \\
\hline
\end{tabular}

Table 5 shows that $35(87.5 \%)$ the respondents had a first degree with the remaining 5 $(12.5 \%)$, have a first degree. A deduction from the above is that majority of the respondents 
are diploma holders teaching at the two public basic schools in Adansi Atobiase in the Adansi South District of the Ashanti Region of Ghana.

\section{Analysis of Items}

The analyses of the items are based on the four research questions which are as follows:

1. Which ICT resources are available to the basic school teachers in Adansi Atobiase for incorporating ICT in teaching and learning?

2. Which factors influence teachers' usage of ICT resources in teaching and learning?

\section{Research Question One (1)}

The first research question sought to find out ICT resources that are available to the basic school teachers in Adansi Atobiase for incorporating ICT in teaching and learning. The responses are presented in Table 6 below.

Table 6

ICT Resources Available to the Basic School Teachers in Adansi Atobiase

\begin{tabular}{|c|c|c|c|c|c|}
\hline ICT Resources & $\begin{array}{l}\text { Always } \\
\text { Available } \\
\end{array}$ & $\begin{array}{l}\text { Sometimes } \\
\text { Available } \\
\end{array}$ & $\begin{array}{l}\text { Not } \\
\text { Available }\end{array}$ & $\mathbf{F}$ & $\%$ \\
\hline $\begin{array}{l}\text { 1. Is your school having all the ICT } \\
\text { available resources to facilitate teaching } \\
\text { and learning }\end{array}$ & - & $5(12.5 \%)$ & $35(87.5 \%)$ & 40 & $100 \%$ \\
\hline $\begin{array}{l}\text { 2. What are some of the available ICT } \\
\text { resources available in your school }\end{array}$ & & & & & \\
\hline 3. ICT Teacher & $30(75.0 \%)$ & $5(12.5 \%)$ & $5(12.5 \%)$ & 40 & 100 \\
\hline 4. Laptop & - & $10(25.0 \%)$ & $30(75.0 \%)$ & 40 & $100 \%$ \\
\hline 5. Computers & $\begin{array}{l}20 \\
(50.0 \%)\end{array}$ & $\begin{array}{l}5 \\
(12.5 \%)\end{array}$ & $\begin{array}{l}15 \\
(37.5 \%)\end{array}$ & 40 & $100 \%$ \\
\hline 6. Projectors & - & $\begin{array}{l}5 \\
(12.5 \%)\end{array}$ & $\begin{array}{l}35 \\
(87.5 \%)\end{array}$ & 40 & $100 \%$ \\
\hline 7. ICT Lab & $\begin{array}{l}5 \\
(12.5 \%)\end{array}$ & $\begin{array}{l}5 \\
(12.5 \%)\end{array}$ & $\begin{array}{l}30 \\
(75.0 \%)\end{array}$ & 40 & $100 \%$ \\
\hline 8. Internet Access & - & - & $\begin{array}{l}40 \\
(100 \%)\end{array}$ & 40 & $100 \%$ \\
\hline
\end{tabular}

Source: Field Survey (2017)

Table 6 reveals the ICT resource available for teachers in teaching at basic schools in Adansi Atobiase. There are 2 items which provided responses on the ICT resources available. Majority of respondents 35 out of 40 representing $87.5 \%$ indicated that ICT resources are not available in basic school in Adansi Atobiase while 5 out of 40 representing 12.5\% expressed that it is sometimes available. Again on the issue of some of the ICT resource available for teaching in basic schools in Adansi in the Adansi South District of the Ashanti Region of Ghana, majority of respondents $30(75.0 \%)$ expressed that ICT teacher is always available in their school, $5(12.5 \%)$ also indicated that ICT teacher is sometimes available whiles 5 $(12.5 \%)$ also indicated that ICT teacher is not available. The implication from the above result is that ICT teachers are available in basic school schools in Adansi Atobiase in the Adansi South District of the Ashanti Region of Ghana. The above results are consistent with 
a study Ayebi-Arthur (2009) who asserted that staff development is one of contributing factors to the effective integration of ICT in the classroom.

The above results are consistent with a study by Bingimlas (2009) who reviewed the existing literature on the necessary elements to enable pre-service and in-service teachers to apply ICT as a meaningful pedagogical tool. They recommended that schools provide teachers with solid evidence supporting the positive impact of technology-based and student-centered instruction on student learning and achievement on standardized tests. For instance, schools can provide opportunities for pre-service teachers to observe a variety of examples and models, which they can then apply with real learners. Schools need to help pre-service teachers understand difficulties they may face when they begin to use ICT in their classrooms, and present effective strategies for addressing them.

In addition, majority of respondents, $30(75.0 \%)$ indicated that laptop is not available in their schools while $10(25.0 \%)$ also indicated that it is sometimes available. This means that laptop as an ICT resource is very scarce in basic schools in Adansi Atobiase of the Ashanti Religion of Ghana. Moreover, majority of respondents, 20 (50.0\%) indicated that computers are always available in their schools while $5(12.5 \%)$ indicated that is sometimes available while $15(37.5 \%)$ indicated that is not available. This means that computers are available at some schools but in some schools too is not available.

Furthermore, majority of respondents, $35(87.5 \%)$ indicated that projectors are not available in basic schools in Adansi Atobiase whiles 5 (12.5\%) indicated that it is sometimes available. Again majority of respondents, 30 (75.0\%) indicated that ICT lab is not available in their schools, $5(12.5 \%)$ indicated that it is available while $5(12.5 \%)$ also indicated that is sometimes available. The implications of this are that, most of the basic schools in Adansi Atobiase does not have ICT lab. Also majority of respondents 40 (100\%) indicated that internet access is not available in basic schools in Adansi Atobiase.

The above results are consistent with a study by Buabeng-Andoh (2012) who asserted that ICT incorporation in the classroom often does so base on their beliefs about good learning and what fits easily into the existing conceptual and social organization of classroom. Teachers intensively used information technology emphasized the importance of using ICT for facilitating students' participation in progressive inquiry, collaborative learning, and the learners' active engagement in the knowledge formation process. The author further added that most basic schools in Africa including Ghana basic ICT resources like computers, ICT lab, internet access and ICT teachers. Also a study by Chen (2008) posited that call ICT incorporating in the Ghana education system cannot be realized without ICT resources.

Table 7

\begin{tabular}{|c|c|c|}
\hline Response & Frequency & Percent \\
\hline Yes & 2 & 5.0 \\
\hline No & 38 & 95.0 \\
\hline Total & 40 & 100.0 \\
\hline
\end{tabular}

It can be seen from table 7 above that as many as $(95.0 \%)$ of respondents responded in the negative while the remaining $2(5.0 \%)$ responded in the positive. From the above, it is evidently clear that all the basic schools in Adansi Atobiase do not have enough computers for studies. In the researcher's interaction with the ICT teachers of most of the basic schools 
in Adansi Atobiase, it came out that with a total students' population of 120, there are only five (5) computers in the laboratory that are in good condition. A personal observation at all the school revealed that most of the computers in the various schools' laboratories were really old. It was also observed that some of the computers had also broken down. The researchers were told by the ICT teachers that the broken down machines have been there for a while because no funds have been allocated to send them for repairs and in some cases buy some parts that have broken down.

Respondents were asked whether they even get the chance or are permitted to use the laboratory and for how many hours for those who want to use them. Their response is presented in Table 8 below.

Table 8

\begin{tabular}{|c|c|c|}
\hline Response & Frequency & Percent \\
\hline Less than an hour & 38 & 95.0 \\
\hline $1-3$ hours & 2 & 5.0 \\
\hline Total & 40 & 100.0 \\
\hline
\end{tabular}

Table 8 reports that as many as $38(95.0 \%)$ of the respondents claimed they can only use or have access to the laboratory in less than an hour in a week. The remaining $2(5.0 \%)$ said they get the opportunity to use the laboratory $1-3$ hours in a week. This outcome is not surprising considering the fact that there are limited machines in the various school laboratories coupled with huge populations in the schools. The researchers in their interaction with the various ICT teachers asked them how they are able to manage the students' population with the computers available.

The teachers in their response said their schools' timetables were drawn in such a way that the students come to the laboratory according to their classes. The teachers told the researcher that students with larger class numbers are made to pair both the chairs and computers. This the researcher conceded is a recipe for disaster since majority of the students will not get access to the computers and would finished school half-baked in the use of computers. It was also revealed that the use of the internet which can provide a nice platform to enhance learning and teaching process for both teachers and students were non-existent in all two schools used for the study.

\section{Research Question Two (2)}

The second research question sought to find out factors that influence teachers' usage of ICT resources in teaching and learning. This response is presented in the below table.

Table 9

\begin{tabular}{|c|c|c|c|c|c|}
\hline Factors & & Agreed & Disagreed & $\mathbf{F}$ & $\%$ \\
\hline 1. & Availability of ICT resources & $\begin{array}{l}40 \\
(100.0 \%)\end{array}$ & - & 40 & $100 \%$ \\
\hline 2. & Students readiness to embrace technology & $\begin{array}{l}40 \\
(100.0 \%)\end{array}$ & - & 40 & $100 \%$ \\
\hline 3. & Teachers readiness to embrace technology & $\begin{array}{l}35 \\
(87.5 \%)\end{array}$ & $\begin{array}{l}5 \\
(12.5 \%)\end{array}$ & 40 & $100 \%$ \\
\hline & Availability of technical support & $\begin{array}{l}25 \\
(62.5 \%)\end{array}$ & $\begin{array}{l}15 \\
(37.5 \%)\end{array}$ & 40 & $100 \%$ \\
\hline & Stable power supply & $\begin{array}{l}10 \\
(25.0 \%)\end{array}$ & $\begin{array}{l}30 \\
(75.0 \%)\end{array}$ & 40 & $100 \%$ \\
\hline
\end{tabular}




\begin{tabular}{llllll} 
6. Intention to facilitate teaching and learning & $\begin{array}{l}40 \\
(100.0 \%)\end{array}$ & 40 & $100 \%$ \\
\hline
\end{tabular}

Source: Field Survey (2017)

Table 9 reveals the factors that influence teachers' usage ICT resource in teaching and learning. There are 6 items which provided responses on the factors influencing teachers' usage of ICT resources in teaching and learning. All the respondents 40 (100\%) agreed that availability of ICT resources is a factor that influence teachers' usage of ICT in teaching and learning.

Also all the respondents $40(100 \%)$ agreed that students' readiness to embrace technology is a factor that influences teachers' usage of ICT in teaching and learning. Again majority of respondents $35(87.5 \%$ ) agreed teachers' readiness to embrace technology is a factor that influences teachers' usage of ICT in teaching and learning whiles 5 (12.5\%) disagreed that teacher's readiness to embrace technology is a factor that influence teachers' usage of ICT in teaching and learning.

Again, all the teachers' respondents $40(100 \%)$ agreed that availability of technical support is a factor that influences teachers' usage of ICT in teaching and learning. Again, majority of the teachers' respondents $30(75.0 \%)$ disagreed that stable power supply is a factor that influence teachers' usage of ICT in teaching at basic schools in Adansi Atobiase whiles 10 (25.0\%) agreed that stable power supply is a factor that influences teachers' usage of ICT in teaching at basic schools in Adansi Atobiase. Also all the respondents 40 (100\%) agreed that intention to facilitate teaching and learning is a factor that influences basic school teachers in Adansi Atobiase to use ICT in teaching.

The above results are in-consistent with a study by Cubukcuoglu (2013) who asserted that ICT can help revitalize teachers and students. This can help to improve and develop the quality of education by providing curricular support in perceived difficult subject areas. To achieve these objectives, teachers need to be involved in collaborative projects and development of intervention change strategies, which would include teaching partnerships with ICT as a tool. The author further added that teachers' attitudes are major predictors of the use of new technologies in instructional settings.

Teachers' attitude toward ICT shapes not only their own ICT experiences, but also the experiences of the students they teach. According to Cowie (2008), three conditions are necessary for teachers to introduce ICT into their classrooms; teachers should believe in the effectiveness of technology, teachers should believe that the use of technology will not cause any disturbances, and finally teachers should believe that they have control over technology. Ertmer (2012) also posited that training efforts are generally welcomed by teachers but consistent support and extensive training is necessary in order for them to consider themselves able to integrate ICT in their teaching methodologies.

Fakeye (2010) also postulated that innovative pedagogical practices involving ICT usage by teachers in teaching is good for enhancing their teaching. Fakeye (2010) concludes that, the benefits of ICT will be gained when confident teachers are willing to explore new opportunities for changing their classroom practices by using ICT. According to Fan, (2012) the use of ICT will not only enhance learning environments but will also prepare the next generation for their future lives and careers. 


\section{Key Findings of the Study}

\section{SUMMARY OF MAJOR FINDINGS}

A descriptive survey was employed for the study. A questionnaire was used to gather data from basic school teachers in Adansi Atobiase and selected through stratified and simple random sampling. The collected data was analyzed in simple percentages.

The first research question was to identify the ICT resources available for the teachers. The study found out that basic school teachers in Adansi Atobiase do not have all the ICT available resources to facilitate teaching and learning. The study also found out that ICT resources such as ICT teacher, laptop, computers, projectors, ICT laboratory and internet access are not available at basic schools in Adansi Atobiase.

The second research question was to identify the factors that influence the teachers' usage of ICT resources in teaching and learning. It emerged from the study that availability of ICT resources, students' readiness to embrace technology, teachers' readiness to embrace technology, availability of technical support, stable power supply and intention to facilitate teaching and learning are the factors that influence the teachers usage of ICT resources in teaching and learning in basic schools in Adansi Atobiase.

\section{CONCLUSIONS}

It can be concluded that there is lack of availability of ICT resources like computers, laptops, projectors and ICT laboratory in basic schools in Adansi Atobiase. The study also concluded that most of basic school teachers in Adansi Atobiase are aware of the importance of ICTs but they do not have the requisite training and skill for effective introduction of ICT in teaching and learning at basic schools. Those who have them basically use them for entertainment or relaxation.

\section{Recommendations}

From the findings and conclusions of this study, the researcher strongly recommends that ICT basic resources like computers, laptops and infrastructures should be provided to the basic schools in Adansi Atobiase in the Adansi South District of the Ashanti Region of Ghana for effective use of ICT in teaching and learning at the basic schools since it is the basic stage of equipping the youth with the necessary skills and knowledge for national development.

Basic school teachers in the Adansi South District especially those in Adansi Atobiase should be given the necessary training in ICT usage so that they become familiar with modern pedagogy of imparting knowledge and skills, and possible become part of curriculum structure for their professional training. Lastly, the study recommends that modern ICT laboratories should be built in Adansi Atobiase to accommodate enough students at time looking at their population size for effective and efficient teaching and learning environment.

\section{Acknowledgements}

The researchers want to thank the editorial board of Fair East Publishers.

\section{Conflict of Interest Statement}

No conflict of interest has been declared by the authors.

\section{Funding}

The researchers have not received any support for the publication of this paper. 


\section{References}

Adebi-Caesar, T. E. (2012). Assessment of I.C.T situation in senior high schools, a case study in Lower Manya Krobo District (Unpublished Master's Thesis), Kwame Nkrumah University of Science and Technology, Kumasi.

Afful-Dadzie, F. (2010). Use of ICT by students and teachers in senior high schools in the Sekondi-Takoradi Metropolis (Unpublished Master's Thesis), University of Cape Coast, Cape Coast.

Agyei, D. D., \& Voogt, J. (2011). ICT use in the teaching of mathematics: Implications for professional development of pre-service teachers in Ghana. Education and Information Technologies, 16(4), 423-439.

Amengor, J. (2011). History teachers' perception of ICT in promoting teaching and learning (Unpublished Master's Thesis), University of Cape Coast, Cape Coast.

Amenyedzi, F. W. K., Lartey, M. N., \& Dzomeku, B. M. (2011). The Use of Computers and Internet as Supplementary Source of Educational Material: A Case Study of the Senior High Schools in the Tema Metropolis in Ghana. Contemporary Educational Technology, 2(2), 151-162.

Ampofo, A. J. (2020). Rural housing challenges in the Upper West Region of Ghana: A case study of Kulmasa. International Journal of Management \& Entrepreneurship Research, 2(4), 194-211.

Ampofo, A. J. (2020). Waste disposal management practices in selected senior high schools within the Wa Municipality of Ghana. International Journal of Management \& Entrepreneurship Research, 2(4), 273-290.

Ampofo, A. J (2020). Contributions of the hospitality industry (hotels) in the development of

Wa. International Journal of Advanced Economics, 2(2), 21-38.

Ampofo, A. J. (2020). The nature of mortgage repayment plans in Ghana. Finance \& Accounting Research Journal, 2(3), 91-104.

Ampofo, A. J. (2019). Performance management and appraisal in improving teachers quality: Lambert Academic Publishing.

Ampofo, A. J. (2017). Community and parental influence on Senor High School (SHS) student's career choice: Lambert Academic Publishing.

Ampofo, A. J. (2017). Teachers perception towards pupils with low vision. Lambert Academic Publishing.

Ayebi-Arthur, K., Aidoo, D. A., \& Wilson, K.B. (2009). A study on the use of the Internet in senior high schools in the Cape Coast metropolis of Ghana. Ghana Journal of Education and Teaching, 5, 131-141.

Boakye, K.B., \& Banini, D.A. (2008). Teacher ICT Readiness in Ghana. In K. Toure, T.M.S. Tchombe, \& T. Karsent (Eds.), ICT and changing mindsets in education. ERNWACA / ROCARE.

Bingimlas, K. (2009). Barriers to the Successful Integration of ICT in Teaching and Learning Environments: A Review of the Literature. Eurasia Journal of Mathematics, Science and Technology Education, 5(3), 235-245.

Buabeng-Andoh, C. (2012). Factors influencing teachers' adoption and integration of information and communication technology into teaching: A review of the literature. International information and communication technology (IJEDICT), 8(1), 136-155. 
Chen, C. H. (2008). Why do teachers not practice what they believe regarding technology integration? The Journal of Educational Research, 102(1), 65-75.

Cowie, B., Jones, A., Harlow, A., McGee, C., Millar, Cooper, B., \& Gardiner, B. (2008). Digital horizons: Laptops for teachers' evaluation. Year 9-13 final research Report. Commissioned by the Ministry of Education. The University of Waikato

Cubukcuoglu, B. (2013). Factors enabling the use of technology in subject teaching. International Journal of Education and Development using Information and Communication Technology (IJEDICT), 9(3), 50-60.

Ertmer, P., Ottenbreit-Leftwich, A., Sadik, O., Sendurur, E., Sendurur, P. (2012). Teacher beliefs and technology integration practices: A critical relationship. Computers and Education, 59(2). 423-435.

Fakeye, D. O. (2010). Assessment of English Language teachers' knowledge and use of Information and Communication Technology (ICT) in Ibadan Southwest Local Government of Oyo State. American Eurasian Journal of Scientific Research, 5(4), 56-59.

Fan, C.W., \& Ho, K. K. (2012). A tale of three cities: Review of the development of ICT in school education between Hong Kong, Macau and Singapore. New Horizons in Education, 60(1), 70-82.

Goyal, E., Purohit, S. \& Bhagat, M. (2010). Factors that Affect Information and Communication Technology Usage: A Case Study in Management Education. A Publication of the Association of Management Journal of Information Technology Management, 21.

Idoko, J. A., \& Ademu, A. (2010). The Challenges of Information and Communication Technology for teaching-learning as perceived by agricultural science teachers in secondary schools in Kogi State. Journal of Educational Innovators, 3(2), 43-49.

Inan, F. A., \& Lowther, D. L. (2010). Factors affecting technology integration in K-12 classrooms: a path model. Educational Technology Research and Development, 58(2), 137-154.

Martin, D. (2003). 'Relating the general to the particular: Data handling and historical learning'. In Haydn, T. \& Counsell, C. (Ed.), History, ICT and learning in the secondary school, (pp. 134-151). London: Routledge Falmer. 